\title{
Proximate and Mineral Analysis of Some Wild Leafy Vegetables Common in Benue State, Middle Belt-Nigeria
}

\section{Simon Terver Ubwa1', Raymond Lubem Tyohemba ${ }^{1}$, Barnabas Atsinafe Oshido1, Qrisstuberg Msughter Amua²}

${ }^{1}$ Chemistry Department, Benue State University, Makurdi-Nigeria

${ }^{2}$ Department of Applied Chemistry, Federal University, Dutsin-Ma, Nigeria

\begin{abstract}
The proximate analysis and mineral composition of some commonly grown and consumed leafy vegetables in the middle belt region of Nigeria were studied to determine their nutritional content. They include Ficus thonningii, Annona senegalensis, Emilia coccinea and Hibiscus sabdariffa. The proximate analyses revealed the following range of result in the fresh sample; Moisture(62.32 -93.38\%),Crude Fat ( 0.05-0.71\%), Crude Fibre (1.30-20.15\%), Ash(1.06-2.37\%), Crude Protein(0.03-0.33\%),Carbohydrate (4.16-15.12\%)and Energy value (17.21 to $67.02 \mathrm{~kJ} / 100 \mathrm{~g}$ ) while that for dried samples were Moisture(11.33-28.58\%),Crude Fat (0.57-3.43\%), Crude Fibre (10.51-36.86\%),Ash(4.70-12.77\%), Crude Protein(0.28-1.53\%),Carbohydrate (33.11-62.11\%) and Energy value $(120.57$ to $345.7 \mathrm{~kJ} / 100 \mathrm{~g})$. There was no significant difference between the nutrient and mineral content of the studied vegetables. The wild vegetables contain appreciable amount of essential nutrient molecules and mineral elements needed for the maintenance of good nutritional status and thus can compete favourably with commonly consumed vegetables.
\end{abstract}

Keywords: Proximate, Vegetables, Mineral analysis, Composition , Nutrient

\subsection{INTRODUCTION}

Nigeria is endowed with numerous varieties of useful plants whose fruits, seeds, stems, roots and leaves serve various important roles in medicine and nutrition Adebowale et al (2013). Unfortunately many of such plants have not been put into maximum use except in times of nutritional stress (McBurney et al, 2004). The neglect of these wild food plants has been attributed to the insufficiency of information on their nutritional profile and potential to serve as food security Afolayan \& Jimoh (2009). The United Nation Food and Agriculture Organization (UNFAO) have estimated that the number of undernourished people in developing countries was 824 million in 19901992. In 2010, the number had climbed to 925 million people. The target set at the 1996 world Food summit was to halve the number of undernourished people by 2015 from their number in 1990-1992 (FAO, 2004). This problem of malnutrition can be reduced by encouraging the use of wild vegetables, as they remain the cheapest source of proteins, minerals and vitamins in the diet of many people (Grivetti and
Ogle, 2000; Lyimo et al, 2003). Earlier research on wild mucilaginous vegetable by Ubwa et al (2014) in the same study area had reviewed appreciable amounts of food nutrients in these vegetables and hence their food value is further reiterated.

Ficus thonningii blume is an ever green tree, 6 to $21 \mathrm{~m}$ tall with a rounded to spreading and dense crown sometimes epiphytic. Its leaves are simply flossy, dark green, thin and papery or slightly leathery, margin smooth, elliptic or obovate, sometimes rather elongated or slightly oblanceolate, grouped at end of twinges (Hines and Karlyneckman, 1993; Gidado and Gwargwor, 2013). Ficus thonnigii is widely distributed in upland forest, open grassland, riverine and rocky areas, it's also found in the savannah Davis (1989). It is an eatable plant that is well consumed among the Tiv speaking people of Benue state, Nigeria. It's also believed to have a medicinal value of curing yellow fever.

This article is published under the terms of the Creative Commons Attribution License 4.0

Author(s) retain the copyright of this article. Publication rights with Alkhaer Publications.

Published at: http://www.ijsciences.com/pub/issue/2015-05/

Article Number: V4201505709; Online ISSN: 2305-3925; Print ISSN: 2410-4477 
Annona Senegalesis is found in tropical rain forest as well as the savannah region of Nigeria and other West African countries. It is sometimes described as a small tree or shrubs since it is about 8 feet high Keay et al. (1964). The leaves are sometimes used as vegetable for making soup. The leaves, stem, bark and root of the plant can also be used for medicinal purposes. It has been reported for treatment of ailments such as cancer, cough and for dressing wound (Abdullahi et al. 2003)

Emilia coccinea belongs to the family Compositae (Asteraceae). The members of this family are largely woody herbs or shrubs, a few trees and climbing herbs Olorede, (1984). E coccinea is also known as "tassel flower". It is an erect bushy herb of up to 120 $\mathrm{cm}$ in height. E. coccinea is an ubiquitous weed of waste place and fallow land. The antimicrobial properties of Emilia coccinea and its use for therapeutic treatment have been investigated by a number of researchers worldwide. According to earlier reports (Odugbemi, 2006). Emilia coccinea has been reported for its medicinal properties for the treatment of syphilis, hernia, gonorrhoea, ulcer, 'craw-craw', abscesses of the breast, ringworm, lice, measles, cough etc. In Nigeria, the leaves are eaten cooked as salad or spinach and the fresh juice of the leaves is a remedy for sore eyes (Sofowora, 1982).

Hibiscus Sabdariffa is a shrub belonging to the family of Malvaceae and is thought to be native to Asia or Tropical Africa Gautam (2004). It is a hardy herbaceous shrub that grows well in most soils that are well drained. The plant is about $3.5 \mathrm{~m}$ tall and has a deep penetrating taproot. It has a smooth or nearly smooth, cylindrical, typically dark green to red stems. Leaves are alternate, $7.5-12.5 \mathrm{~cm}$ long, green with reddish veins and long or short petioles. Leaves of young seedlings and upper leaves of older plants are simple; lower leaves are deeply 3 to 5 or even 7 lobed and the margins are toothed (Julia, 1987). It is commonly grown in the middle belt and North Eastern regions of Nigeria (Akanya et al. 1997).

The neglect of some of these vegetables coupled with the increased reduction in their consumption prompted this research. The study was aimed at providing the nutritional profile of some of these indigenous vegetables that are found available in
Benue state, middle belt region in Nigeria as wild plants.

\subsection{MATERIALS AND METHODS}

\subsubsection{Sample Collection and Identification}

The leaves of the vegetables ( $F$. Thonningii, A. Senegalesis, E. Coccinea, H. Sabdariffa) were collected from the wild around Makurdi, Benue State, Nigeria. The leaves were identified and authenticated by a Taxonomist in the Department of Biological Sciences, Benue State University Makurdi.

\subsubsection{Sample Preparation}

The collected plant leaves were cleaned and separated into two portions. The first portion was sliced with a knife into smaller pieces and kept in the fridge for fresh sample analysis. The second portion was spread on an already cleaned laboratory bench for two weeks in the Chemistry laboratory of Benue State University, Makurdi. The dried leaves were later pounded into powder with laboratory mortar and pestle. A portion of the powdered sample was then kept for determination of the various parameters.

\subsubsection{Experimental Analysis}

The proximate analysis (Protein, fats, fibre, ash, moisture and carbohydrates) of the fresh and dry samples of the plant leaves were determined by the method described by AOAC (2000) and the ASEAN Manual of Food Analysis (Pwwastein et al. 2011). The total crude protein was determined by Kjeldahl method. The nitrogen value was converted to protein by multiplying a factor of 6.25 .The crude fat content was determined using soxhlet extraction method. The moisture content of the sample was determined by drying the sample to a constant weight at $105^{\circ} \mathrm{C}$ in an air-oven. The ash and crude fibre were determined using weight loss method. The carbohydrate content was determined using weight difference method. The energy values of the vegetables were calculated using the conversion factor provided by Food and Agricultural Organization (FAO, 2004b). The mineral content of the fresh and dried samples were determined using PG 990 Atomic Absorption Spectrophotometer.

\subsection{RESULTS AND DISCUSSION}

The results for proximate composition and mineral content of the vegetables studied are presented in Tables 1 and 2 below respectively.

Table 1. Proximate composition of the studied vegetables 


\begin{tabular}{|c|c|c|c|c|c|c|c|c|}
\hline Parameter & \multicolumn{2}{|c|}{ Ficus thonningii } & \multicolumn{2}{|c|}{ Annona senegalesis } & \multicolumn{2}{|c|}{ Emilia coccinea } & \multicolumn{2}{|c|}{ Hibiscus sabdariffa } \\
\hline Moisture & $83.38 \pm 0.40$ & $13.18 \pm 0.26$ & $62.36 \pm 3.24$ & $11.78 \pm 0.14$ & $93.38 \pm 0.67$ & $28.58 \pm 0.13$ & $86.73 \pm 0.64$ & $11.33 \pm 0.16$ \\
\hline Crude Fat & $0.71 \pm 0.20$ & $2.57 \pm 0.16$ & $0.58 \pm 037$ & $2.94 \pm 0.44$ & $0.05 \pm 0.52$ & $0.57 \pm 0.49$ & $0.71 \pm 0.16$ & $3.43 \pm 0.30$ \\
\hline Crude Fibre & $2.31 \pm 1.26$ & $36.86 \pm 0.99$ & $20.15 \pm 1.71$ & $35.21 \pm 3.60$ & $1.30 \pm 1.33$ & $10.51 \pm 0.00$ & $1.47 \pm 0.18$ & $12.48 \pm 0.11$ \\
\hline Ash content & $2.37 \pm 0.69$ & $12.77 \pm 0.01$ & $1.46 \pm 0.16$ & $4.70 \pm 0.00$ & $1.06 \pm 0.49$ & $7.06 \pm 0.01$ & $1.49 \pm 0.28$ & $9.13 \pm 0.36$ \\
\hline $\begin{array}{l}\text { Carbohydrate } \\
\text { content }\end{array}$ & $10.90 \pm 1.06$ & $33.11 \pm 0.81$ & $15.12 \pm 4.69$ & $44.60 \pm 3.17$ & $4.16 \pm 0.21$ & $53.01 \pm 2.01$ & $9.36 \pm 0.43$ & $62.11 \pm 0.72$ \\
\hline $\begin{array}{l}\text { Energy value } \\
\text { (cal) }\end{array}$ & 51.31 & 161.65 & 67.02 & 345.70 & 17.21 & 218.29 & 44.83 & 285.43 \\
\hline
\end{tabular}

*Mean \pm S.D of triplicate determinations

Table 2. Mineral content of the studied vegetables (mg/100g)

\begin{tabular}{|c|c|c|c|c|c|c|c|c|}
\hline $\begin{array}{l}\text { Paramete } \\
\mathbf{r}\end{array}$ & \multicolumn{2}{|c|}{ Ficus thonningii } & \multicolumn{2}{|c|}{ Annona senegalesis } & \multicolumn{2}{|c|}{ Emilia coccinea } & \multicolumn{2}{|c|}{ Hibiscus sabdariffa } \\
\hline Sodium & $2.36 \pm 0.001$ & ND & ND & ND & $13.13 \pm 0.004$ & $11.63 \pm 0.007$ & ND & ND \\
\hline Potassium & ND & ND & ND & ND & ND & ND & ND & ND \\
\hline $\begin{array}{l}\text { Magnesiu } \\
\mathrm{m}\end{array}$ & $\begin{array}{l}20.93 \pm 0.00 \\
2\end{array}$ & $\begin{array}{l}186.89 \pm 0.00 \\
5\end{array}$ & $\begin{array}{l}64.11 \pm 0.00 \\
2\end{array}$ & $\begin{array}{l}191.50 \pm 0.00 \\
4\end{array}$ & $13.10 \pm 0.002$ & $\begin{array}{l}187.13 \pm 0.00 \\
1\end{array}$ & $\begin{array}{l}37.74 \pm 0.00 \\
1\end{array}$ & $257.22 \pm 0.001$ \\
\hline Lead & ND & ND & $0.17 \pm 0.001$ & $3.65 \pm 0.003$ & $0.86 \pm 0.00$ & $3.64 \pm 0.003$ & $0.02 \pm 0.002$ & $2.00 \pm 0.004$ \\
\hline Nickel & $1.53 \pm 0.003$ & $27.25 \pm 0.003$ & $1.11 \pm 0.001$ & $2.59 \pm 0.004$ & $0.64 \pm 0.006$ & $1.67 \pm 0.003$ & $1.88 \pm 0.001$ & $0.98 \pm 0.007$ \\
\hline
\end{tabular}

*Mean \pm S.D of triplicate determinations

The moisture content of the fresh samples ranged from 62.32 to $93.38 \%$ with the least in A.senegalesis and the highest in E.coccinea. These fresh vegetables have high moisture contents. Foods with moisture content of 50-95 percent are referred to as high moisture foods (Desrosier et al. 1997). The moisture content in the dried samples ranged from 11.33 to $28.58 \%$ with the least and highest in H.sabdariffa and E.coccinea respectively. The high moisture content for the fresh vegetables are in conformity with the data released by the US Department of Agriculture (USDA) standard which gives a range of $72.4-95.2$ $\%$ moisture content for fresh fruits and vegetables with exception of $A$. senegalensis (USDA, 2009) although all the results are within the 60 to $83 \mathrm{~g} / 100 \mathrm{~g}$ recommended by Food and Agricultural Organization (FAO, 1968) for fresh vegetables and fruits.The moisture content in the dried samples are also high compared to the $8.7 \%$ reported by Pearson (1976) and $7.7 \%$ reported by Tijjani et al. (2013) in $F$.
Thonningi and A. Senegalesis respectively. The high moisture content of these vegetables will however render them susceptible to microbial degradation and subsequently high perishability (Yusuf and Muritala, 2013).

The fibre content of the fresh sample ranged from 1.30 to $20.15 \%$ with the least in E. coccinea and the highest in A. senegalesis. The crude fibre of the dried samples ranges from 10.51 to $36.86 \%$. The crude fibre content of all the samples is above the $8 \mathrm{~g} / 300 \mathrm{~g}$ recommended by WHO/EU (2000) for vegetables. The high values of the crude fibre are in agreement with previous research for similar leafy vegetables (Ekpo 2007; Yisa et al. 2010) .The ash content of the fresh sample ranged from 1.06 to $2.37 \%$ with the lowest in E. coccinea and the highest in $F$. thonningi. In the dried sample, the ash content is in the range of 4.70 to $12.77 \%$. The least and highest values were found in $A$. senegalensis and $F$. thonningi 
respectively. All the fresh samples had ash content that is within USDA standard of $0.2-1.9 \%$ reported by USDA (2009) for fresh vegetables except $F$. thonningii which had a higher ash content of $2.37 \%$ but was still within the range of $0.1-4.4$ percent found in most fresh vegetables (Kirk and Sawyer, 1991). The high ashes content of $F$. thonningiis an indication of its high mineral content. All the vegetables can be good source of minerals because of their high ash content

The crude fat content of the fresh sample ranged from 0.05 to $0.71 \%$ with the least in E.coccinea and the highest in $F$. thonningi and $H$. sabdariffa. The range of 0.57 to $3.43 \%$ was found in the dried sample with E. coccinea having the least value while $H$. sabdariffa has the highest amount of crude fat. The results are in conformity with similar studies on leafy vegetables with range of $0.5-7.62 \%$ (Hanif and Musdasar, 2006; Sobowale and Olatidoye, 2011). The fat content of all the fresh samples of the vegetables studied are below the $2 \mathrm{~g} / 300 \mathrm{~g}$ reported by WHO/EU (2000) for vegetables while those of the dried samples are all above the standard except that of $E$. Coccinea. The consumption of these vegetables is healthy for the body since excess fat in the body causes cardiovascular disorders (Sobowale and Olatidoye, 2011).

The crude protein content of the fresh samples was in the range of 0.03 to $0.33 \%$. The dried samples have a range of 0.28 to $1.53 \%$. The least amount of crude protein in both the fresh and dried samples was found in E.coccinea while the highest for both is found in F.thonningi. The results for both fresh and dried samples are in conformity with that of the USDA (2009) which gives a range of $0.3-2.0 \%$ for protein in vegetables. The energy values for the fresh samples were in the range of 17.21 to $67.02 \mathrm{~kJ} / 100 \mathrm{~g}$ while that of the dried samples were in the range of 120.57 to $345.7 \mathrm{~kJ} / 100 \mathrm{~g}$. A.Senegalensis has the highest energy content while E.Coccinea has the least. It can be seen that these vegetables generally have low energy values and therefore can be used for weight loss. The carbohydrate content of the fresh samples was in the range of $4.16-15.12 \%$ while that of dried samples was 33.11-62.11\%. Complex carbohydrates which are found in vegetables are preferred by the body since they slow the conversion to simple sugars like glucose and decrease insulin level which will subsequently help in burning fats (Mercola, 2014).

It very eminent from table 2 that, dry vegetable samples had levels of minerals higher than their fresh counterparts. This could be attributed to the concentration of the minerals on drying. Magnesium recorded the highest levels in all the samples ranging from 13.10 to $64.11 \mathrm{mg} / 100 \mathrm{~g}$ and 186.89 to 257.22 $\mathrm{mg} / 100 \mathrm{~g}$ for fresh and dried samples respectively.
These levels of $\mathrm{Mg}$ are however below the National Agency for and Drug Administration and Control (NAFDAC, 2010) recommended daily intake (RDI) of $375 \mathrm{mg} / 100 \mathrm{~g}$. The levels of Manganese in the samples ( 2.63 to $242.86 \mathrm{mg} / 100 \mathrm{~g}$ ) were found to be above the RDI of $2 \mathrm{mg} / 100 \mathrm{~g}$ recommended by NAFDAC except in fresh sample of F.thonning $i$ where it was found below detection limit. In addition, the presence of copper in the dried samples of F.thonningi, A.senegalensis and E.coccinea were aboive the RDI of $1 \mathrm{mg} / 100 \mathrm{~g}$. Other trace elements including sodium, Nickel and Zinc were also detected in the samples. Similar levels of these minerals had been reported in our earlier studies on wild mucilaginous vegetables in the study area (Ubwa et al. 2014).

Analysis of variance (ANOVA) was carried out based on multiple statuses of the variables to be compared. The result of the ANOVA test for the equality of means between the different samples of fresh vegetables under which various food nutrients was recorded showed a probability value of 0.9808 ( $p>0.05$ ) indicating no significant difference between the nutrient content obtained from the different samples of fresh vegetables. A similar trend was observed for dried vegetable samples for the same category of food nutrients with a probability value of 0.9581 ( $p>0.05$ ) indicating the absence of significant difference for nutrient content of the various dried vegetable samples.

Statistical analysis on the mineral content of fresh vegetables revealed that, there is no significant difference between F.thonningi, A.senegalesis, E.coccinea and H.sabdariffa. This is evidenced by the probability value of 0.3892 which is greater than the alpha level of 0.05 (5\% level of significance). This similar trend was observed for the mineral content of the dried vegetable samples with p-value of 0.7923 being greater than the alpha level of 0.05 indicative of no significant difference.

\subsection{CONCLUSION}

This study has revealed that the leaves of Ficus Thonningii, Annona Senegalensis, Emilia Coccinea and Hibiscus Sabdariffa contain some appreciable amount of essential nutrient molecules and mineral elements needed for the maintenance of good nutritional status and they compete favourably with commonly consumed vegetables.

\section{COMPETING INTEREST}

Authors have declared that no competing interest exist.

\section{REFERENCES}


1) Abdullahi, M., Muhammad, G., Abduikadir, N.U., 2003. Medicinal andEconomic plants of Nupe land, 1st edition, jube Evans publisher, Bida,Nigeria

2) Adebowale, K.D., Nwokocha, L.M., Agbaje, W.B., 2013. Composition of Cissus populnea stem. Journal of Food Composition and Analysis, 30, 41-46. http://dx.doi.org/10.1016/j.jfca.2013.01.001

3) Afolayan, A.J., Jimoh, F.O., 2009. Nutritional quality of some wild leafy vegetables in South Africa. http://dx.doi.org/10.1080/09637480701777928

4) Akanya, H.O., Oyeleke, S.B., Jigam, A.A., Lawal, F.F., 1997. Analysis of Sorrel drink. Nigerian Journal of Biochemistry, 12, 77-79.

5) AOAC ., 2000. Association of Official Analytical Chemist. Official Method of Food Analysis $17^{\text {th }}$ edition of AOAC International, Washington DC. USA.

6) Davies, N.T., 1989. The Effect of Dietary Fibre On Mineral Availability. Journal of Plant Food, 3, 113-123

7) Desrosier, W.W., Desrosier, J.N., 1977. The Technology of Food Preservation. Westport, Connecticut: AVI publication.Com http://dx.doi.org/10.1002/food.19790230123

8) Ekop, A.S., 2007. Determination of chemical composition of Gnetum africanum (AFANG) seeds. Pakistan Journal Nutrition, 6(1), 40-43. http://dx.doi.org/10.3923/pjn.2007.40.43

9) FAO (Food and Agricultural Organisation)., 1968. Food composition table for use in Africa. Food and Agricultural Organisation of the United Nations, Rome, Italy. http://dx.doi.org/10.2458/azu_acku_pamphlet_ha4570_6_a63 4 1997

10) FAO (Food and Agriculture Organization)., 2004. The state of food security in the world. Rome, Italy: Economic and Social Department

11) FAO (Food and Agricultural Organization)., 2004. Food energy-methods of analysis and conversion factors. Agriculture and consumer protection. Available: www.fao.org/docrep

12) Gautam, R.D., 2004. Sorrel-A lesser known source of medicinal soft drink in India. Natural Product Radiance, 3 (5), 338-342.

13) Gidado, O.G., Gwargwor, Z.A., 2013. Assessment of Anti nutritive Factors and Nutrients. International Journal of Applied Science and Engineering. 1, 5-9.

14) Grivetti, L.E., Ogle, B.M., 2000. Value of traditional foods in meeting macro and micronutrient needs: The wild plant connection. Nutr. Res. Rev. 13, 31- 46. http://dx.doi.org/10.1079/095442200108728990

15) Hanif, R., Mudasar, I., 2006. Use of Vegetables as Nutritional Food. Journal of Agricultural and Biological sciences. 1, $18-20$

16) Hines, D.A., Karlyneckman, A., 1993. Proximate Composition of Eatable Vegetables. Columbian journal of applied science, Vol 2 pp 1-4.

17) Julia, F., 1987. Roselle, In: Fruits of warm climates, edited by Morton J, Miami, 1987, 281-286. Available on http://www.hort.purdue.edu/newcrop/morton/roselle.html.

18) Keay, R.W.J., Onochie, C.F.A., Stafield, D.P., 1964. Nigerian trees. Nigerian Natural Press ltd. Ibadan. Pp58
19) Kirk, R.S., Sawyer, R., 1991. Pearson's Composition and Chemical Analysis of Foods $9^{\text {th }}$ Edition. Longman scientific and technical, Essex,England.

20) Lyimo, M., Temu, R.P.C., Mugula, J.K., 2003. Identification and nutrient composition of indigenous vegetables of Tanzania. Plant Foods and Human Nutrition, 58, 82- 92.

21) McBurney, R.P., Griffin, C., Greenberg, D.C., 2004. The nutritional composition of African wild food plants: From Pre-compilation to utilization. Journal of Food Composition $\begin{array}{llll}\text { and } & \text { Analysis. } & 17, & 277-\end{array}$ http://dx.doi.org/10.1016/j.jfca.2004.03.008

22) Mercola, J., 2014. Beginner plan: Carbohydrates. www.mercola.com 8/01/2015

23) NAFDAC (National Agency for Food and Drug Administration and Control). 2010. Nutrition, Health and other Claims on Food Regulations.

24) Odugbemi, T., 2006. Outlines and pictures of medicinal plants from Nigeria. University of lagos press,Nigeria. Pp 283-285.

25) Olorode, O., 1984. Taxonomy of West Africa flowering plants. Longman, London. Pp 445

26) Pearson, D., 1976. Chemical analysis of Foods. New York: Chemical publishing Company Inc.

27) Pwwastein, P., Song, T.E., Kantasubrata, J., Craven, G.R.R., Juprasong, K., 2011. ASEAN Manual of Nutrient Analysis. Institute of Nutrition, Manihol.

28) Sobowale, S.S., Olatidoye, O.P., 2011. Nutritional Potential and Chemical Value of Some Tropical Leafy Vegetables Consumed In South West Nigeria. Journal of Science and Multidisciplinary Research, 3, 55 -60.

29) Sofowora, E.A., 1982. Medicinal plants and traditional medicine in Africa. John Wiley and sons. Chiclester. Pp198.

30) Tijjani, M.A., Abdurahaman, F.I., Abba, Y.S., Idris, M. Baburo, B.S., Mala, G.A., Dungus, M.H., Aji, B.M. Abubakar, K.I., 2013. Evaluation of Proximate and Phytochemical Composition of Leaves of Annona Senegalensis Pers. Journal of Pharmaceutical and Scientific Innovation. 2(1).

31) Ubwa, S.T., Tyohemba, R.L., Oshido, B.A., Amua, Q.M., 2014. Chemical analysis of some wild underutilized mucilaginous vegetables and a domesticated vegetable in Benue State, Nigeria, British Journal of Applied science and Technology. $\quad 4(32), \quad 4566-4574$ http://dx.doi.org/10.9734/bjast/2014/12241

32) USDA ( United State Department of Agriculture) (2009)National Nutrient Database for Standard Reference Release 22. Nutrient data Laboratory. http://www.ars.usda.gov/ba/bhnrc/ndi Date accessed: 14th February 2014

33) World Health Organisation/Europe. 2000. CINDI dietary guide. Denmark: WHO Regional Office for Europe, Copenhagen, 2000

34) Yisa, J., Egila, J.N., and Darlinton, A.O., 2010. Chemical Composition of Annona Senegalensis from Nupe land, Nigeria. African Journal of Biotechnology.

35) Yusuf, A.O., Muritala, R.O., 2013. Nutritional Evaluation and Phytochemical Screening of Common Plants used in Smallholder Farming System.Vol 14 No2. 